\title{
Essential of Central Bank's Regulatory Policy to Strengthen Green Banking Practice and Reporting in a Country
}

\author{
Sutap Kumar Ghosh \\ Assistant Professor \\ Department of Finance and Banking, Islamic University, Bangladesh \\ E-mail: ansutap@gmail.com \\ Protap Kumar Ghosh \\ Associate Professor \\ Business Administration Discipline, Khulna University, Bangladesh \\ E-mail: pkghosh1982@gmail.com
}

\author{
Sabrin Chowdhury \\ Student at Business Administration Discipline \\ Khulna University, Bangladesh \\ E-mail: sabrinchowdhury2011@gmail.com
}

Received: Sep. 3, 2018 Accepted: Nov. 11, $2018 \quad$ Published: December 1, 2018

doi:10.5296/ajfa.v10i2.13599 URL: https://doi.org/10.5296/ajfa.v10i2.13599

\begin{abstract}
This paper has been designed to investigate the current scenarios of Green Banking practices in Indian sub-continent and to disclose how central bank's direct regulatory policy strengthens mandatory Green Banking practice and reporting in a country. This study is mainly a descriptive one based on review of different published literature. Relevant information has been collected from different off-line and online sources. Present scenario of Green Banking practices and central bank Green Banking policies in Indian sub-continent (India, Bangladesh and Pakistan) are disclosed first and then how central bank regulatory
\end{abstract}


policies can create a competitive advantage to accelerate Green Banking practice in a country are disclosed. After critical evaluation of collected information, we find that if the central bank formulates Green Banking policies and enforces mandatory Green Banking practices and reporting for financial institutions rather than voluntary practices, a significant and distinguished progress in Green Banking practices and reporting may take place to ensure sustainable banking practice in a country.

Keywords: Green banking, Practice and reporting, Central bank, Regulatory policy, Sustainability 


\section{Introduction}

Sustainability has become very critical issue nowadays. Continuous global warming and climate change make it more complex nowadays. To ensure greater sustainability, the restless efforts are to be carried out for sustainable environment management across the world (Cogan, 2008). The governmental authority as well as the direct emitters and other stakeholders especially financial institutions should also play an important role in this regard (Jha \& Bhoome, 2013 ). Out of financial institutions, banking sector is the main economic negotiator that influence lending and financing different projects of different business houses in different industries. Banking sector can promote sustainable operation in various business sectors for environmental sustainability (Ravi, 2013). Although Banking in-house activities are not too much involved with the environment, the impacts of the activities of its clients are important. So, by adopting Green Banking policies into its operations, mostly in financing and investing, banks can influence its clients (Nath et al., 2014). In twenty-first century, the most important issue in different operation is to safeguard sustainable ecological balance in every aspect. The term 'Green' refers a broad range of social, ethical and environmental dimensions (Ullah, 2013). Indian Banks Association (IBA, 2014) explained Green Banking is like a normal bank, which considers all the social and environmental/ecological factors with an aim to protect the environment and conserve natural resources. Green Banking is also known as ethical or sustainable banking that accelerate environment friendly practices in order to reducing the carbon emission from banking operations (Bai,2011).

The core objective of Green Banking is to protect ecological environment, and natural resources comprising biodiversity (Lalon, 2015). Green Banking ensure effective and efficient usages of natural resources with greater responsibility to reduce wastage of natural resources to protect environment and biodiversity (Habib et al., 2014). Rajesh and Dileep (2014) stated that Green Banking is a convention of transformation of banking objectives from "profit only" to "profit with responsibility". According to Bihari (2011), the motives for going green are many. The key factors are to reduce energy consumption, increase consumers' awareness in environmentally-friendly goods and services social responsibilities etc. Green Banking promotes environment friendly technological advancement, operational efficiency and client habits in banking sector. It's a smart and proactive way of thinking for future sustainability (Nath et al., 2014). Green Banking is an eco-friendly approach that reduces environmental degradation to make this earth more livable (Goyal \& Joshi, 2011). Green Banking is termed as sustainable banking or ethical banking that includes green mortgages, mobile banking, green credit cards and savings accounts, online banking, roof gardening, and green financing, green checking accounts etc. (Azam, 2012). Green banking involves two approaches. First one is to transform all internal banking operations to adopt suitable ways to utilize renewable energy, automation and other effective environment friendly procedures to lessen environmental degradation from banking operation. Second one is that while financing to a firm, the entire bank should assess environmental riskiness of that financing to uphold environment friendly projects and business (Afgan et al, 2014). Green Banking helps the bank to be sustainable in economic, environment, and social dimensions to reduce negative impact on environment (Nath et al, 2014). 
A series of studies had been conducted to investigate the relationship between corporate environmental and financial performance. Few studies found a positive relationship between financial performance and environment friendly activities of the company (Russo \& Fouts, 1997). A study was conducted by Hart \& Ahuja $(1994,1996)$ to check the relationship between green banking and financial performance of the banks and eventually concluded that green banking practice and financial performance of the bank was negatively related in the short-run but in the end it became positive. Similarly, the positive relationship between green baking practice and financial performance of the bank was also found (Printer et al., 2006; Mathieson; 2008; Galdeano-Gomez, 2008; Nanda \& Bihari, 2012). Although few studies revealed positive relationship between green banking practice and profitability, an inverse relationship was also found in some studies as well (Blum, 1995 \& Worrell et al., 1995). Although the contradictory financial performance has been found in previous studies, the necessity of green banking to reduce environmental degradation cannot overlook. With a view to accelerating Green Banking practices, this study has been designed to detect how the central bank regulatory policies relating to Green Banking practices and reporting intensifies the green banking practices and reporting by other banks in a country.

\section{Methodology}

This study is mainly a descriptive one based on review of different published literature. Indian subcontinent comprising Bangladesh, Pakistan and India has been selected to resolve our research question. The relevant published documents have been collected from various journals, online and offline sources. After critical review of these documents, the relevant information has been presented through diagram, tables and descriptive way. Throughout the review process, we have tried to show the current scenarios of green banking practice and reporting in Indian subcontinent and the degree of involvement of central bank in this regard. Finally, we have tried to expose how the central bank direct involvement in Green Banking practice and reporting accelerates and establishes distinguished position in Green Banking practice and reporting in a country.

\section{Green banking practice in Indian Sub-continent}

\subsection{Scenario of Green banking Practice in Bangladesh}

Bangladesh is a fast growing economy in South Asia that suffers from Global Warming. Because of negative impact of climate change on Bangladesh economy, Bangladesh Bank (central bank of Bangladesh) has been trying to contribute in enhancing Green Banking practice in Bangladesh and eventually a circular was issued on Green Banking on February 27, 2011 (Islam \& Das, 2013). Bangladesh Bank also ensures Green Banking Practices in its head and branch offices. The whole activities of BB provide an effective message to all the financial organizations about the implementation Green Banking activities by other banks in Bangladesh (Islam \& Kamruzzaman, 2015). BB issued guidelines for the financial sector on "Environment Risk Management (ERM)"in 2011 to entertain the environmental and social issues by various financial institutions in Bangladesh and these guidelines become mandatory for the financial institution to entertain environmental and social issues in every aspects of its lending, developing and investing activities. After that, Bangladesh Bank developed and 
released Policy Guidelines on "Green Banking" that proved an intensive policy and strategic framework for Green Banking practices by different financial institution especially banks (Hasina \& Afgan S.M. 2014).

Green Banking policy guideline was divided into three phases- Phase-I, Phase-II and Phase-III. During Phase-I ( until December 31, 2011),policy formulation \& governance, incorporation of environmental risk in CRM, initiating in-house environment management, introducing green finance, creation of climate risk fund, introducing green marketing, online banking, supporting employee training, consumer awareness \& green event, reporting green banking practices etc. initiatives were taken. During Phase-II ( until December 31, 2012), Bangladesh bank tried to achieve these targets i.e. sector-specific environmental policies, green strategic planning, setting up green branches, improved in-house environment management, formulation of bank specific environmental risk management plan \& guidelines, disclosure \& reporting of green banking activities etc. During Phase-III (until December 31, 2013), the objectives of BB were to designee, introduce innovative products, and report in standard format with external verification (Bangladesh Bank, 2011; Ahmed, 2012).

Later on this policy guideline of $\mathrm{BB}$ enforced others banks to adopt and implement sustainable banking practices in formal and structured way in a three-phased approach with specific timelines for implementation of each phase ( out of which final phase was to be implemented by Dec. 2013).BB rearranged this implementation deadline in 2013(BB annual report 2013). Bangladesh Bank (2012) described the objective of Green Banking in its annual report and focused on the usages of resources with responsibility and giving priority to environment and society as a part of corporate social responsibility (CSR) activity to make this world livable without much damage environment. Bangladesh Bank divided its Green Banking activities into in-house and other than in-house activities. 'In-house activity' denotes those activities that are involved and performed in the office building conspiring daily green operation, networking, office automation, other initiatives that reduce paper works etc. (Shakil et al., 2014). Whereas, 'Other than in-house activities' represents only refinance scheme and BB launched this refinance facility in 2011 and in 2012, it disbursed around BDT 2 billion in various financial institutions at only 5\% rate of interest (Bhal \& Sarta, 2012). Shakil et al., (2014) stated that Bangladesh Bank authority considered Green Banking Unit, Green Banking Policy, Green Banking Budget, Online banking, Mobile banking, Green financing, Environment risk rating activities as Green Banking practice. In Bangladesh, 47 banks of56scheduledBanks as well as 11 financial institutions out of 32 institutions have direct and indirect exposure in green finance. Although Green Banking practice is uprising, still now Green Finance by Banks and financial institutions is focused on mostly indirect Green Finance (Islam, 2015). 


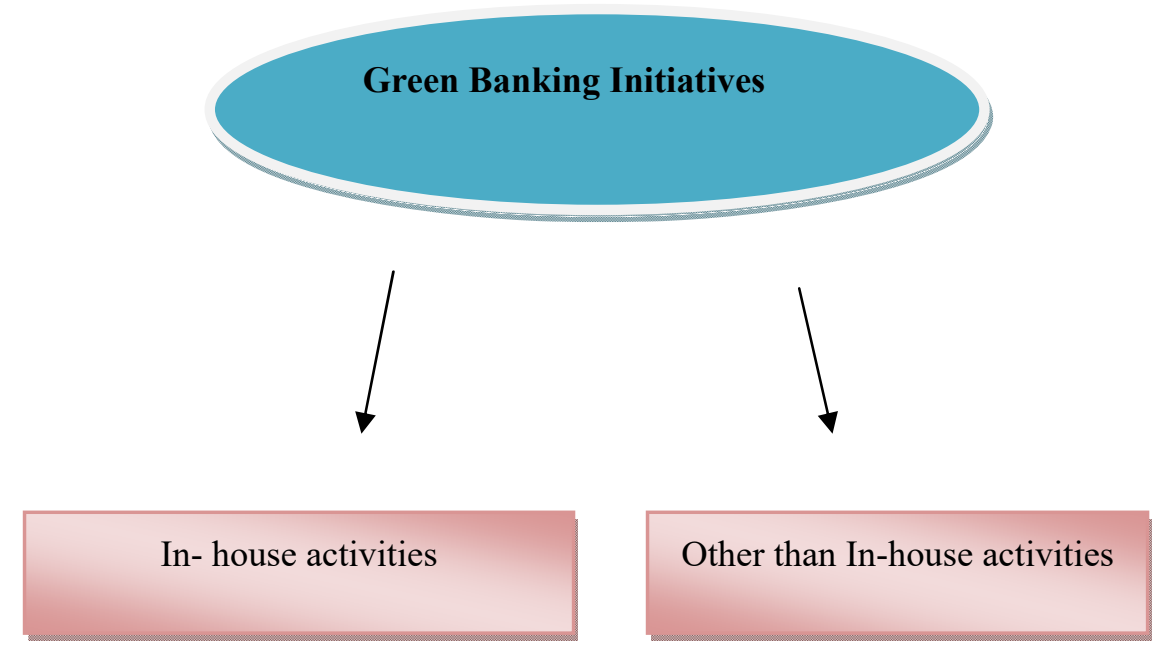

Figure 1. Green Banking Initiatives by Bangladesh Bank

Source: Annual report-2012, Bangladesh Bank

3.1.1 Green banking practices by various banks

Bangladesh Bank primarily selected ten commercial banks (Bank Asia ltd, Dutch Bangla Bank 1td, Eastern Bank 1td, Islami Bank Bangladesh ltd, Mutual Trust Bank ltd, Prime Bank ltd, Pubali Bank ltd, Standard Chartered Bank, Shahjalal Islami Bank ltd and Trust Bank ltd) based on CAMEL rating and Risked Based Capital Adequacy (RBCA) measurement, which have been implementing sustainable Green Banking activities in Bangladesh. BB also considers the environmental issues to give approval for new branches. Nine banks have been established newly and out of which six banks have already formulated its Green Banking Policy as well as 8 banks have established Green Banking Unit (GBU). 29 financial institutes out of total 31 have constructed its Green Banking guidelines approved by respective Board of Directors and also opened Green Banking Unit (GBU). 28 financial institutions have organized own green office guidelines for doing their in-house green activities (Islam, 2015).Name of various bank using Green Banking practices has been described in following table. 


\section{Ml Macrothink}

Table 1. Name of the banks doing Green banking practices in Bangladesh

\begin{tabular}{|c|c|c|c|c|}
\hline $\begin{array}{c}\text { State Owned } \\
\text { Commercial } \\
\text { Bank }\end{array}$ & $\begin{array}{l}\text { Specialized } \\
\text { Banks }\end{array}$ & \multicolumn{2}{|c|}{ Private Commercial Banks } & $\begin{array}{l}\text { Foreign Commercial } \\
\text { Banks }\end{array}$ \\
\hline $\begin{array}{l}\text { 1. Sonali } \\
\text { 2. Rupali } \\
\text { 3. Janata } \\
\text { 4. Agrani }\end{array}$ & $\begin{array}{l}\text { 5. BKB } \\
\text { 6. } \\
\text { RAKUB } \\
\text { 7. BDBL } \\
\text { 8. BASIC }\end{array}$ & $\begin{array}{l}\text { 9. } \text { The City } \\
\text { 10. U.C.B.L } \\
\text { 11. AB Bank } \\
\text { 12. IFIC } \\
\text { 13. National } \\
\text { 14. Uttara } \\
\text { 15. Pubali U } \\
\text { 16. Eastern } \\
\text { 17. NCCBL } \\
\text { 18. Dhaka } \\
\text { 19. Southeast } \\
\text { 20. Prime } \\
\text { 21. DBBL } \\
\text { 22. Mercantile }\end{array}$ & $\begin{array}{ll}\text { 23. } & \text { One } \\
\text { 24. } & \text { EXIM } \\
\text { 25. } & \text { Premier } \\
\text { 26. } & \text { Standard } \\
\text { 27. } & \text { FSIBL } \\
\text { 28. } & \text { BCBL } \\
\text { 29. } & \text { MTBL } \\
\text { 30. } & \text { Trust } \\
\text { 31. } & \text { Bank Asia } \\
\text { 32. } & \text { Al-Arafa } \\
\text { 33. } & \text { ICB } \\
\text { 34. } & \text { Islami } \\
\text { 36. } & \text { BRAC } \\
\text { 37. } & \text { Jamuna } \\
\text { 38. } & \text { Shahaialal }\end{array}$ & $\begin{array}{ll}\text { 39. } & \text { CB of Ceylon } \\
\text { 40. } & \text { St. Cert } \\
\text { 41. } & \text { SBL } \\
\text { 42. } & \text { HABIB } \\
\text { 43. } & \text { NBP } \\
\text { 44. } & \text { Citi N.A } \\
\text { 45. } & \text { HSBC } \\
\text { 46. } & \text { WOORI } \\
\text { 47. } & \text { Al-Falah }\end{array}$ \\
\hline
\end{tabular}

Source: Annual Report-2015, Bangladesh Bank

Table 2. Fund allocated and used in Green Banking Activities

\begin{tabular}{|c|c|c|c|c|c|c|c|c|}
\hline \multicolumn{5}{|c|}{ Annual Allocated Fund, 2015 (BDT in millions ) } & \multicolumn{4}{|c|}{ Utilization of Funds, 2015 (BDT in millions) } \\
\hline $\begin{array}{l}\text { Type of } \\
\text { Bank/FI }\end{array}$ & $\begin{array}{l}\text { Green } \\
\text { Finance }\end{array}$ & $\begin{array}{c}\text { Climate } \\
\text { Risk } \\
\text { Fund }\end{array}$ & $\begin{array}{c}\text { Marketing } \\
\text {, Training } \\
\text { and } \\
\text { Capacity } \\
\text { Building }\end{array}$ & Total & $\begin{array}{l}\text { Green } \\
\text { Finance }\end{array}$ & $\begin{array}{c}\text { Climate } \\
\text { Risk } \\
\text { Fund }\end{array}$ & $\begin{array}{c}\text { Marketing } \\
\text {, Training } \\
\text { and } \\
\text { Capacity } \\
\text { Building }\end{array}$ & Total \\
\hline SOCBs & $7,846.80$ & 220.00 & 410.00 & $8,476.80$ & 663.76 & 12.40 & 3.54 & 679.70 \\
\hline SDBs & 210.00 & 0.20 & 0.10 & 210.30 & 5.10 & 0.00 & 0.00 & 5.10 \\
\hline PCBs & $196,895.83$ & 367.58 & $1,924.96$ & $199,188.37$ & $102,718.93$ & 195.30 & 11.88 & $102,926.10$ \\
\hline FCBs & $57,718.61$ & $1,178.00$ & $40,465.40$ & $99,362.01$ & $20,620.27$ & 27.48 & 0.00 & $20,647.75$ \\
\hline New Banks & $1,862.52$ & 0.00 & 0.00 & $1,862.52$ & 638.41 & 2.39 & 0.00 & 640.80 \\
\hline Total & $264,533.76$ & $1,765.78$ & $42,800.46$ & $309,100.00$ & $124,646.47$ & 237.57 & 15.42 & $124,899.45$ \\
\hline FIs & $24,586.09$ & 47.03 & \begin{tabular}{|l|}
7.88 \\
\end{tabular} & $24,641.00$ & $4,685.35$ & 3.21 & 0.55 & $4,688.00$ \\
\hline $\begin{array}{l}\text { Grand } \\
\text { Total }\end{array}$ & $289,119.85$ & $1,812.81$ & $42,808.34$ & $333,741.00$ & $129,331.82$ & 240.77 & 15.96 & $129,587.45$ \\
\hline
\end{tabular}

Source: Annual Report-2015, Bangladesh Bank 
Table 3. Major Green Banking Activities in Bangladesh in 2015

\begin{tabular}{|l|l|l|}
\hline Issue & Bank & FI \\
\hline No. of banks/FIs that have Green Banking unit & 56 & 30 \\
\hline No. of banks/FIs that have Green Banking policy & 55 & 30 \\
\hline No. of banks/FIs that have Green office guides & 54 & 30 \\
\hline No. of environmentally risky projects & 13,704 & 796 \\
\hline Financing No. of environmentally risky projects & 11,587 & 574 \\
\hline Total amount disbursed risk rated projects (in million BDT) & $547,319.42$ & $28,561.70$ \\
\hline No. of solar power based branches & 433 & 4 \\
\hline No. of solar power based ATM/SME units & 251 & N/A \\
\hline$\%$ of online branches & $75.07 \%$ & N/A \\
\hline Green financing (in million BDT) & $124,646.47$ & $4,685.35$ \\
\hline$\%$ of green finance of loan disbursement & $0.55 \%$ & $2.12 \%$ \\
\hline BDT used from climate risk fund (in millions) & 237.57 & 3.21 \\
\hline $\begin{array}{l}\text { BDT used for green marketing, training and development (in } \\
\text { millions })\end{array}$ & 15.42 & 0.55 \\
\hline
\end{tabular}

Source: Annual Report-2015, Bangladesh Bank

\subsubsection{Green Finance}

Green Finance contains both direct and indirect finances. The sources of direct Green Finance are Bank's own fund or funds from Bangladesh Bank for environment friendly renewable energy and other projects. Projects having ETP or alike system are included in the indirect finance (Bhal, \& Sarta, 2012). Moreover, 47 scheduled banks and 11 financial institutions have had exposure in Green Finance in direct and indirect form. Although Green Finance practice is uprising, still now Green Finance by scheduled banks and financial institutions is focused on indirect Green Finance. Direct Green Finance by banks and financial institutions is only $7.45 \%$ of total Green Finance and $0.63 \%$ of total loan disbursement in a quarter (BB annual report, 2015).

Table 4. Green Finance until December, 2015 (BDT in millions)

\begin{tabular}{|l|l|l|l|}
\hline Types of banks/FIs & \multicolumn{1}{|c|}{$\begin{array}{c}\text { Direct Green } \\
\text { Finance }\end{array}$} & \multicolumn{1}{|c|}{$\begin{array}{c}\text { Indirect Green } \\
\text { Finance }\end{array}$} & $\begin{array}{c}\text { Total Green } \\
\text { Finance }\end{array}$ \\
\hline SOCBs & 540.89 & 122.87 & 663.76 \\
\hline SDBs & 5.10 & 00.0 & 5.10 \\
\hline PCBs & $6,834.88$ & $95,884.05$ & $102,718.93$ \\
\hline FCBs & 238.73 & $20,381.54$ & $20,620.27$ \\
\hline New Banks & 419.87 & 218.54 & 638.41 \\
\hline Total & $8,039.47$ & $116,607.00$ & $124,646.47$ \\
\hline FIs & $1,596.82$ & $3,088.53$ & $4,685.35$ \\
\hline Grand Total & $9,636.29$ & $119,695.53$ & $129,331.82$ \\
\hline
\end{tabular}

Source: Annual Report -2015, Bangladesh Bank 


\section{Macrothink}

\subsection{Current Scenario of Green Banking Practice in India}

India is one of the fastest-developing nations in Asia and also considered as major future economy in the world (ETD 2015). The most important role in its economic growth story is played by the growing industrial sector. But, her industries face the challenges of controlling environmental impact of their business (Sahoo \& Nayak, 2008; Singh, 2016). India is the fourth biggest emitter in terms of per capita emission of greenhouse gases (Mohan, 2015). According to Central Pollution Control Board (CPCB) of India, the major polluting industries are aluminum smelter, caustic soda, pesticides, pulp and paper, sugar, fertilizers, tanneries, textiles, chemicals/pharmaceuticals etc. (CPCB, 2016 ; Sahoo \& Nayak, 2008). Traditionally, India promotes sustainable development procedure for her business expansion and eventually has already started carbon tax system for business operation (Sreesha, 2014). Indian Government has planned to sanction 10,192.83 corer Rupees in the annual budget for the fiscal year 2016-17 to increase eco-friendly sustainable renewable energy resources for supplementing traditional energy requirements in the country (Gandhi, 2016). Moreover, Reserve Bank of India (RBI) has become conscious about the role of banks for sustainable development. RBI established Institute of Development and Research in Banking Technology (IDRBT) in March 1996 as an autonomous center for development and research in banking technology. Among all the major initiatives started by IDRBT, Green Banking Best Practices were published in August, 2013. The IDRBT has suggested the standard rating for green efficient banks and banking practices in India and where both infrastructure development and daily operations of the banks are to be considered under this rating system. The Green Rating Standard was termed as "Green Coin Rating”.

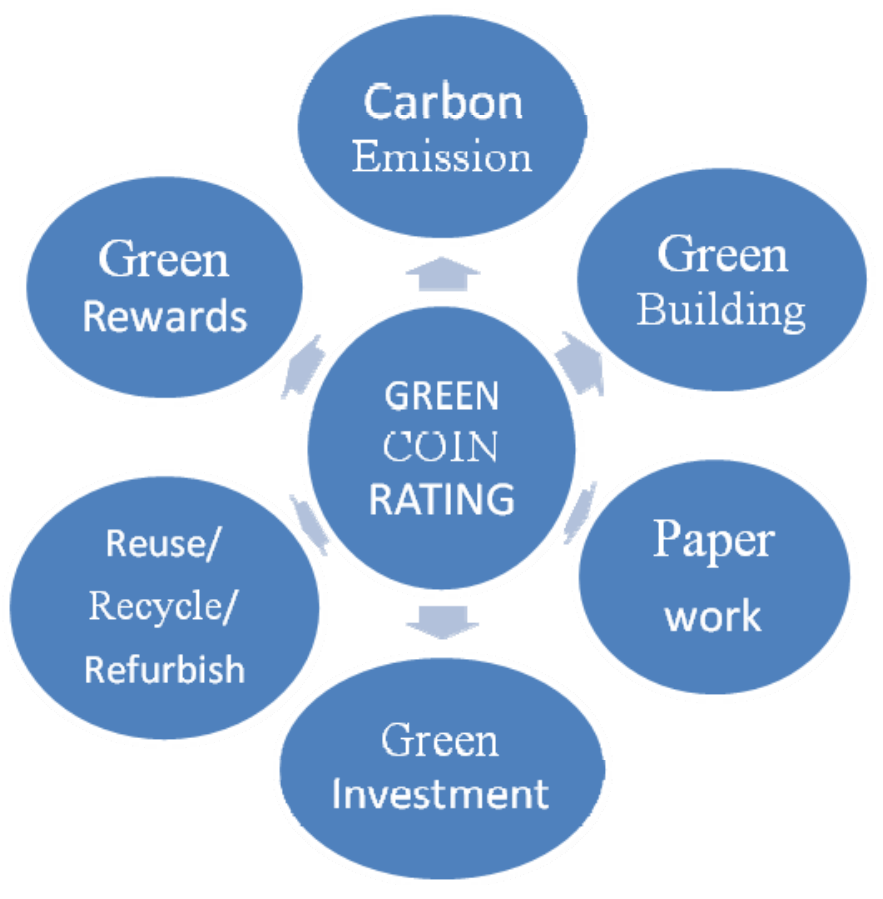

Figure 2. Dimention of Green Coin Rating system by IDRBT, India 
In 2015, RBI targeted lending to social infrastructure and small renewable energy projects with a view to giving an auxiliary stimulus to Green Financing. The Securities and Exchange Board of India (SEBI) has designed required framework for the issuance and listing requirements of Green Bonds. India entered into the Green Bond market in 2015, with a total of US 1.1 billion dollar of green bonds (Gandhi, 2016). RBI is continually urging the banks to act responsibly to facilitate sustainable development in India and highlighting the need to create institutional mechanisms to preserve sustainability (Chowdhury, 2014). Some banks India has already started Biometric ATM, Solar-based ATM, White-labeled ATMs, SMS alerts, Mobile banking, green loan, online banking services in banking operation (Jha \& Bhome, 2013). Dipika ( 2015) reported that in India different type of Green Banking servises like Mobile banking, ATM services, Oneline banking etc are funtioning in different banks. She also reported that some Oneline banking services like fund transfer to self-accounts, third party fund transfer, inter-bank payee fund transfer, PPF transfer, setting up standing instruction, e-tax payment, e-ticketing, bill payments, visa money transfer, online application for IPO etc. are given without manual intervention to reduce carbon foot prints in banking operation. Innovative Green Banking financial products developed by Indian banks are reducing carbon emission directly or sometimes indirectly. These banks can introduce green funds to provide green loan to the climate conscious customers to invest in the environmental friendly projects (Bihari \& Pandey, 2015). Green Banking Initiatives are taken by both public sector banks (holding more than $50 \%$ stock by the government) and private sector banks (holding more than $50 \%$ stock by the private shareholders). The public sector and private sector banks has initiated green initiatives in India are given below.

Table 5. Green Banking Practice by various banks In India

\begin{tabular}{|l|l|}
\hline Public Sector Banks & Private Sector Banks \\
\hline 1. State Bank of India & 1. ICICI Bank \\
2. Punjab National Bank & $\begin{array}{l}\text { 2. HDFC Bank } \\
\text { 3. Bank of Baroda }\end{array}$ \\
$\begin{array}{l}\text { 3. Canara Bank } \\
\text { 5. Central Bank }\end{array}$ \\
$\begin{array}{l}\text { 4. YES Bank } \\
\text { 6. IDBI Bank }\end{array}$ \\
\hline
\end{tabular}

Source: Money Control (2015)

\subsection{Scenario of Green banking Practice in Pakistan}

A resilient nation like Pakistan has a serious need of practicing the concept of green economy into its policies (Samad \& Manzoor, 2011). Green growth for Pakistan can signify effective and efficient use of natural resources and reduction of the climate change vulnerabilities (Shaheen \& Khan, 2002). Planning Commission of Pakistan (2012) asserted that the concept 
of Green Economy is to be incorporated into policies and discourse. Relationship of the Green Economy and growth needs to be examined in an innovative and focused manner regarding the economy along with productivity. Green Financing is a fairly new term in Pakistan. Some commercial banks in Pakistan have started exploring its segment operating with energy efficient technologies. Here, the part of microfinance banks in Pakistan is worth mentioning since they literally opened up the scope of Green Financing for the large banks (Farrukh, 2014).However, structuring Green Financing in this country can be a complex procedure because it is uncanny and still unconventional for the country as it necessitates more legal creativeness compared to the conventional financing. Financing rules and requirements for alternate energy are not much developed yet. Moreover, awareness among borrowers is still low. Reacting to the problem, State Bank of Pakistan (SBP) has recently revised its prudential regulations of housing finance to let banks offer loans to individual customers providing affordable solar power solutions at their resident as part of home loans. These endeavors will create a platform for Green Finance to grow in Pakistan (Thombre, 2011). State Bank of Pakistan has taken different measures to expand activities of Green Banking among all banks and instructed them to follow (Hasnain and Afgan, 2014)."Green Banking Unit" (GBU) has been established in the State Bank of Pakistan (SBP) to coordinate and gear up the Green Banking initiatives. According to SBP Annual Performance Review for the year 2014-15, this unit has a vision of sustainable and Green Banking orientation of banking practices by incorporating resource efficiency, renewable energy and environmental protection in banking operations and products/services. In this regard, SBP prepared a concept paper on "Green Banking" during the year providing several recommendations for future initiatives (Bhatti, 2015). The GBU has enhanced co-ordination with multilateral agencies to work out proposals with joint initiatives. Besides, SBP also joined Sustainable Banking Network (SBN) of International Finance Corporation (IFC). So, the grass is certainly greener on the Green Financing side in Pakistan. The financial institutions of Pakistan should provide their best efforts towards Green Financing for making customer more aware about the significance of Green Financing and sustainable banking practices to enhance Green Banking activities (Samad \& Manzoor, 2011). The names of banks involved in Green Banking practices in Pakistan are given below.

Table 6. Name of banks using Green Banking practices in Pakistan

\begin{tabular}{|l|}
\hline \multicolumn{1}{|c|}{ Name of Banks } \\
\hline 1. \\
2. Bational Bank of Pakistan Alfalah Limited \\
3. Allied Bank \\
4. $\mathrm{MCB}$ \\
\hline
\end{tabular}

Source: Pakistan Economic Survey (2015) 


\section{Comparative picture of green banking among three countries}

To accelerate Green Banking practices in Bangladesh, Bangladesh Bank (BB) formulated the Green Banking Policy guideline and Strategy Framework in 2011 that requires other banks to implement a wide range of Green Banking activities in a three-phased approach (Masukujjaman \& Akhtar, 2013). BB not only formulated the policy but also provided technical supports for Green Banking implementation (Nath A., 2015). Moreover, BB adopted Green Banking practices in its own in-house operations and also reports scenario of overall Green Banking practices by different scheduled banks and financial institutions. Online banking and ATM facilities are considered as the first step to implement green banking in Bangladesh as it lessens lots of paper works and satisfies the principle of cleanliness at bank. 47 Scheduled banks of Bangladesh have its own Green Banking Policy Guidelines, Green Office Guide as well as have Green Banking Unit (GBU) for conducting in-house green activities (Rahman M S. \& Barua S.,2016).

Reserve Bank of India is much behind to be involved in Green Banking practices in its own operations and reporting overall Green Banking practices by other banks in India as compared Bangladesh Bank in Bangladesh. Mandatory regulatory policies have not been taken to implement Green Banking practices by others banks in India (Chaurasia, 2014; Trehan, 2015).But it cannot be claimed that Reserve Bank of India is much reluctant initiating Green Banking practices in India. Public sector banks are emphasizing more on green initiatives as compared to the Private sector banks but these Private sector banks are generally inclined toward green initiatives for instance net banking, mobile banking etc.(Sahoo \& Nayak, 2008; Goyal \& Joshi, 2011). In December 2007, RBI issued a circular (RBI 2007-2008/216) emphasizing the importance of sustainable banking practice by designing institutional mechanism to act responsibly in order to contributing sustainable development in India (Rahman et al., 2013). In 2015, India entered into the Green Bond market and also used Green Coin Rating system where banks would be judged based on the rate of carbon emission out of their operations, the amount of reuse, refurbish (IDRBT, 2013). To align financial systems with the sustainability domineering, India welcomes new Green Finance initiatives, issues Green Bond, ten solar based ATM has been set up in Coimbatore circle as per IAD model and 2016 is set to be the year of Green Finance(Gandhi, 2016). Even after all these initiatives, it can be claimed that there is a lack of formal regulatory polices by Reserve Bank of India to accelerate mandatory Green Banking practices and reporting by other banks in India. Consequently, very little number of banks as compared to total numbers is involved in Green Banking practices and reporting (Nishi Sharma, 2011; Rajput, Kaur et al., 2013; Sudhalakshmi \& Chinnadorai 2014).

In Pakistan Green Banking is relatively a new approach. The banking sectors have started taking baby steps into this segment (Ragupathi \& Sujatha, 2015). Although structuring Green Banking is a complex procedure in Pakistan because Green Banking is unconventional and still uncommon for the country (Kandavel, 2013), a few number of commercial banks have taken steps to be involved in Green Banking (Sreesha, 2014). The State Bank of Pakistan (SBP) has established a "Green Banking Unit" (GBU) in its operations with a view to 
coordinating and gearing up its initiatives on Green Banking and making their customer more aware about the importance of green financing and sustainable banking practices (Iyer, 2015). But, still now SBP cannot introduce specific regulatory guidelines for mandatory Green Banking practices for banking sectors and much behind in implementing and reporting overall Green Banking practices by others banks in Pakistan.

Table 7. Comparative picture of country-wise Green Banking practice

\begin{tabular}{|l|c|c|c|}
\hline \multicolumn{1}{|c|}{ Name of Green Banking Initiatives } & Bangladesh & India & Pakistan \\
\hline E-statement rather than paper statement for customers & $\sqrt{ }$ & $\sqrt{ }$ & \\
\hline Online communications & $\sqrt{ }$ & $\sqrt{ }$ & \\
\hline Use daylight to reduce the usages electricity & $\sqrt{ }$ & & \\
\hline Usages of energy efficient devise & $\sqrt{ }$ & & \\
\hline Conversion of vehicles into CNG & $\sqrt{ }$ & $\sqrt{ }$ & \\
\hline Both sides paper usages & $\sqrt{ }$ & & \\
\hline Use eco-font for printing & $\sqrt{ }$ & & \\
\hline Web based e-tendering system slips & $\sqrt{ }$ & & \\
\hline $\begin{array}{l}\text { Sending payment slips, reimbursement } \\
\text { electronically }\end{array}$ & $\sqrt{ }$ & $\sqrt{ }$ & \\
\hline Mobile banking, Tele banking, ATM services & & $\sqrt{ }$ & \\
\hline Issuance of green bond & $\sqrt{ }$ & $\sqrt{ }$ & \\
\hline $\begin{array}{l}\text { Provides Green Services ( i.e. Green deposit, Green } \\
\text { mortgages and loans, Green credit cards, Green checking } \\
\text { accounts etc) }\end{array}$ & $\sqrt{ }$ & $\sqrt{ }$ & \\
\hline Green Banking Practices evaluation system & & & \\
\hline Solar powered operations & & & \\
\hline
\end{tabular}

N.B. This table is prepared based on availability of information

\section{Conclusion}

After an intensive investigation, we eventually declare that Bangladesh Bank, central bank of Bangladesh, has directly included Green Banking practice in its operation and established specific policies and guidelines for other financial institutions to be involved in Green Banking practice as well. BB not only follows up the Green Banking practices by other financial institutions and but also discloses overall status Green Banking practices in Bangladesh in its annual reports. In Bangladesh, 47 Scheduled banks out of 56 and29 out of 31 financial institutions have formulated their own Green Banking Policy Guidelines and have also formed Green Banking Unit for pursuing Green Banking activities. Whereas in India, the Reserve bank of India is not too much involved with Green Banking policy making, monitoring and reporting overall Green Banking practices by different financial institutions. Although a few numbers of public and private banks of India have already started Green Banking practices in its operations, the current status of overall green banking practices by various financial institutions is not at satisfactory level because of lack of central bank's regulatory policies for mandatory Green Banking practices and reporting for other banks. In Pakistan, Green Banking is totally a new concept in banking sector and remains at very early 
stage although State Bank of Pakistan has already established 'Green Banking Unit' to enhance Green Banking practices in Pakistan. Therefore, after critical review of existing literature, we can eventually conclude that Central bank's Green Banking policies can enhance significant and distinguishing Green Banking practices and reporting in a country.

\section{References}

Ahmed, S. U. (2012). Green Banking: Advancement and Opportunities. Keiei to Keizai, 92(1-2), 1-12.

Afgan, S., Saleem M., \& Abbasi M G. (2014). Concept Paper of Green Banking, Infracture,House and SME Finance Department, Pakistan.

Ahuja, N. ( 2015). Green Banking in India: A Review of Literature. International Journal for Research in Management, 4(1), 1-6.

Azam, S. (2012). Green Corporate Environment: Green Banking and Green Financing. The Financial Express, July 04, p.7.

Bai, Y. (2011). Financing a Green Future. MS thesis: Lund, Sweden, Retrieved from: http://lup.lub.lu.se/luur/download?func=downloadFile\&recordOId=2203222\&fileOId=22032 2

Bangladesh Bank. (2011, 2012). Annual Report on Green Banking, Green Banking and CSR Department, Bangladesh.

Bangladesh Bank. (2013). Annual report on Green Banking Report. Green Banking and CSR Department, Bangladesh

Bangladesh Bank. (2015). Annual Report on Green Banking. Green Banking and CSR department, Bangladesh.

Bhal \& Sarta. (2012). Green Banking-The New strategic imperative. Asian Journal of Research in Business Economics and Management, 2(2), 1-20.

Bhatti, R. (2015). SBP sets up Green Banking Unit. Business Recorder of Pakistan, November 04. p.3-4.

Bihari, S.C. (2011). Green Banking-Towards Socially Responsible Banking in India. International Journal of Business Insights and Transformation, 4(1), 82-87.

Blum, J.P. (1995). Corporate environmental responsibility and corporate economic performance: an empirical study of the environmental involvement of the top 150 US and Swiss banks. Journal of International Business Studies, 26(3), 682.

Chaurasia, A. K. (2014). Green Banking Practices In Indian Banks. Journal of Management and Social Science (JOMASS., 1(1), 41-54.

Chowdhury, S. (2014). A Study on Green Banking Initiatives of Selected Private and Public Sector Banks in India. International Journal of Research (IJR), 1(7), 807- 814. 
Cogan, D.G. (2008). Corporate Governance and Climate Change: The Banking Sector. A Ceres Report, Risk Metrics Group Inc., New York.

CPCB. (2016). 17 Categories of the major polluting industries [Online]. Available from: http://cpcb.nic.in/faq2.php, (accessed 19 June 2016).

Dipika. (2015). Green Banking in India: A Study of Various Strategies Adopt by Banks for SustainableDevelopment. National Conference on Emerging Trends in Engineering, Management and Scien, Resource Development Cell, Ganga Institute of Technology and Management.195-205.

ETD. (2015). About India. $18^{\text {th }}$ International Symposium on Electronic Theses and Desertions Evolving Genre of ETDs for Knowledge Discovery, New Delhi, India.

Farrukh, S. (2014). Banking review 2014: Banking System and Economic growth. City Bank N.A Pakistan- Karachi, Lahore.

Galdeano-Gomez, E. (2008). Does an endogenous relationship exist between environmental and economic performance? A resource-based view on the horticultural sector. Environmental and Resource Economics, 40(1), 73-89. https://doi.org/10.1007/s10640-007-9141-4

Gandhi, S. R. (2016). Green finance-Early Initiative: Delivering a Sustainable Financial System in India. UNEP India Inquiry, Mumbai.

Goyal, KA, \& Joshi, V. (2011). A Study of Social and Ethical Issues In Banking Industry. International Journal of Economics and Research, 2(5), 49-57.

Habib, SMA, Ullah, MS, \& Rahman, T. (2014). An Impact Evaluation of Green Initiatives of Bangladesh Bank in Green Banking in Bangladesh. Environmental Risk Management in Banking. Bangladesh Institute of Bank Management (BIBM), Dhaka, p. 93-136.

Hart, S.L., \& Ahuja, G. (1994). Does it pay to be Green? An empirical examination of the relationship between pollution prevention and firm performance. Paper presented at The Annual Meeting of the Academy of Management, Dallas, Texas.

Hart, S.L., \& Ahuja, G. (1996). Does it pay to be Green? An empirical examination of the relationship between emission reduction and firm performance. Business Strategy and the $\begin{array}{lll}\text { Environment, } & 5(1), & 30-37 .\end{array}$ https://doi.org/10.1002/(SICI)1099-0836(199603)5:1<30::AID-BSE38>3.0.CO;2-Q

Hasina S.S., \& Afgan S.M. (2014). Concept Paper on Green Banking Infrastructure. Housing and SME Finance Department, State Bank of Pakistan, Pakistan.

IDRBT. (2013). Green Banking for Indian Banking Sector. Indian Institute for Development and Research in Banking Technology, India.

Indian Banks Association. (2014). Green Banking Innovations: Indian Banks' Association, Retrieved from The Indian Banker: http://www.theindianbanker.co.in/html/sto_5.htm. 
Islam, A., \& Kamruzzaman (2015). Green Banking Practices in Bangladesh. IOSR Journal of Business and Management, 17(4), 37-42.

Islam, M.S., \& Das, P.C. (2013). Green Banking practices in Bangladesh. IOSR Journal of Business and Management, 8(3), 39-44. https://doi.org/10.9790/487X-0833944

Iyer, A. (2015). IDBI Bank to issue five-year green bonds today. Hindustan Times. June 23. pp.1.

Jha, N., \& Bhoome S. (2013). A Study of Green Banking Trends in India. International Monthly Refereed Journal of Research In Management \& Technology, 2(2), 1-6.

Kandavel, D. (2013). Green Banking Initiatives of the Commercial Banks in India. SIT Journal of Management, 3(2), 213-225.

Karunakaran, R. (2014). Green Banking - An Avenue to Safe Environment. Galaxy International Interdisciplinary Research Journal, 2(2), 36-42.

Lalon M.R. (2015). Green Banking: Going Green. International Journal of Economics, Finance and Management Sciences, 3(1), 34-42. https://doi.org/10.11648/j.ijefm.20150301.15

Masukujjaman, \& Akhtar S. (2013). Green Banking in Bangladesh: A Commitment towards the Global Initiatives. Journal of Business and Technology, 8(3), 1-24.

Mathieson, A. (2008). Creating loyalty with the green consumers. Banking New York, 4, 28-29

Mohan, V. (2015). Greenhouse gases: India fourth biggest emitter, but lags far behind top three. The Times of India, pp. 3.

Money Control. (2015). Top Companies in India by Net Profit - BSE. Available from: http://www.moneycontrol.com/stocks/marketinfo/netprofit/bse/index.html

Nanda, S., \& Bihari, S.C. (2012). Profitability in banks of India: an impact study of implementation of green banking. International Journal of Green Economics, 6(3), 217-225. https://doi.org/10.1504/IJGE.2012.050969

Nath, V., Nayak, N., \& Goel, A. (2014). Green banking Practices - A Review of Literature. International Journal of Research in Business Management, 2(4), 45-62.

Sharma, N. (2011). CSR practices and CSR reporting in Indian banking sector. International journal of advanced economics and business management, 1(2), 58-66.

Pakistan Economic Survey. (2015). Highlights of Pakistan Economic Survey- 2014 to 2015. Available from: http://www.finance.gov.pk/survey/chapters_15/Highlights.pdf

Planning Commission. (2014). Pakistan Vision 2025 - One Nation, One Vision. Planning Commission, Ministry of planning, Development and Reform, Government of Pakistan. 
Pinter, E., Deutsch, N., \& Ottmar, Z. (2006). New direction line of sustainable development and marketing in green banking. 22nd IMP Conference, Milan, Italy

Ragupathi, M., \& Sujatha, S. (2015). Green Banking Initiatives of Commercial Banks in India. International Research Journal of Business and Management (IRJBM), 8(2), 74-81.

Rahman, M.S., \& Barua, S. (2016). The Design and Adoptation of Green Banking Framework for Environment Protection: Lessons from Bangladesh. Australian Journal of Sustainable Business and Society, 2(1), 1-19.

Rajesh, T., \& Dileep, A.S., (2014). Role of banks in sustainable economic development through green banking. International Journal of Current Research and Academic Review. 2(12), 136-141.

Rajput, N., Kaura, R, \& Khanna, A. (2013). Indian banking sector towards a sustainable growth: a paradigm shift. International Journal of Academic Research in Business and Social Sciences, 3(1), 290.

Raman, M.M., Ahsan M.A., Hossain M.M., \& Hoq M., (2013). Green Banking Prospects in Bangladesh. Asian Business Review, 2(4), 59-63. https://doi.org/10.18034/abr.v2i2.112

Ravi Meena. (2013). Green Banking: As Initiative for Sustainable Development. Global Journal of Management and Business Studies, 3(10), 1181-1186.

Russo, M.V., \& Fouts, P.A. (1997). A resource based perspective on corporate environmental performance and profitability. Academy of Management Journal, 40(3), 534-559.

Sahitya, U., \& Lalwani, V. (2014). Sustainability in Indian Banking Industry- A Case-Study Approach. International Journal of Commerce, Business and Management, 3(1), 220-229.

Sahoo, P., \& Nayak, B.P. (2008). Green Banking in India. Institute of Economic Growth Discussion Paper Series. University of Delhi, No. 125, New Delhi, India.

Samad, G., \& R. Manzoor (2011). Green Growth: An Environmental Technology Approach. The Pakistan Development Review, 50(4), part11 (winter), pp.471-490.

Shaheen, \& Khan R. (2002). Adaptation to Climate Change in the Context of Sustainable Development and Equity: The Case of Pakistan. Sustainable Development Policy Institute (SDPI), Pakistan.

Shakil H.M., Azam G.K., Tasnia M., \& Munim H.Z. (2014). An Evaluation of Green Banking Practices in Bangladesh. IOSR Journal of Business and Management, 16(11), 67-73. https://doi.org/10.9790/487X-161146773

Sharma, N., Chaudhury, R., \& Purohit, H. (2015). A Comparative Study on Green Initiatives Taken By Select Public and Private Sector Banks in Mumbai. 8th International Business Research Conference, IES Management College and Research Centre, Mumbai, India. IOSR Journal of Business and Management (IOSR-JBM), p.32-27. 
Singh, M. S. (2016). Sustainability Practices of Indian Banking Industry: An Awareness, Acceptance and Adoption. Radix International Journal of Economics \& Business Management, 5(3), 1-10.

Sreesha, C. (2014). A Study on Green Banking Initiatives of Selected Private and Public Sector Banks in India. International Journal of Research (IJR), 1(7), 24-36.

Sudhalakshmi, K., \& Chinnadorai, K. (2014). Green Banking Practices in Indian Banks. International Journal of Management and Commerce Innovations, 2(1), 232-23

Thombre A.K. (2011). The New Face of Banking: Green Banking. Golden Research Thoughts, 1(7), 1-6.

Trehan, R. (2015). Green banking in India. Journal of Poverty, Investment and Development, 14(3), 27-32.

Ullah, M.M. (2013). Green Banking in Bangladesh- A Comparative Analysis. World Review of Business Research, 3(4), 74-83. 